\title{
Recombinant Interleukin-1-alpha
}

National Cancer Institute

\section{Source}

National Cancer Institute. Recombinant Interleukin-1-alpha. NCI Thesaurus. Code C1754.

A recombinant agent which is chemically identical to or similar to the endogenous protein cytokine interleukin-1 (IL-1). The IL-1 precursor is produced by monocytes, activated macrophages, and other cell types; mature IL-1 is generated by proteolytic cleavage by proteases such as IL-1-beta converting enzyme (ICE). This agent enhances T cell proliferation and B cell growth and differentiation and induces the expression of proinflammatory cytokines. ( $\mathrm{NCl04)}$ 